Taxation and Democracy 
This page intentionally left blank 


\section{TAXATION AND DEMOCRACY}

Swedish, British and American Approaches to

Financing the Modern State

Sven Steinmo

Yale University Press

New Haven and London 
Published with assistance from the Mary Cady Tew Memorial Fund.

Copyright $(\mathcal{O} 1993$ by Yale University.

\section{All rights reserved.}

This book may not be reproduced, in whole or in part, including illustrations, in any form (beyond that copying permitted by Sections 107 and 108 of the U.S.

Copyright Law and except by reviewers for the public press),

without written permission from the publishers.

Designed by Sonia L. Scanlon

Set in Times Roman type by Tseng Information

Systems, Durham, North Carolina

Printed in the United States of America

Library of Congress Cataloging-in-Publication Data

Steinmo, Sven.

Taxation and democracy : Swedish, British, and

American approaches to financing the modern state /

Sven Steinmo.

p. $\mathrm{cm}$.

Includes bibliographical references and index.

ISBN 978-0-300-06721-7

1. Taxation-Sweden. 2. Taxation-Great

Britain. 3. Taxation-United States. I. Title.

HJ2305.S85 1993

$336.2-\mathrm{dc} 20 \quad 93-10364$

CIP

A catalogue record for this book is available

from the British Library.

The paper in this book meets the guidelines for permanence and durability of the Committee on Production Guidelines for Book Longevity of the Council on Library Resources. 
For my love,

Rita 
This page intentionally left blank 